\title{
Synergistic effect between carbon dopant in titania lattice and surface carbonaceous species for enhancing the visible light photocatalysis
}

\author{
R. Kavitha, L. Gomathi Devi* \\ Department of Post Graduate Studies in Chemistry, Central College City Campus, Bangalore University, Dr. Ambedkar Street, Bangalore 560001, India
}

\section{A R T I C L E I N F O}

\section{Article history:}

Received 26 September 2013

Accepted 27 February 2014

\section{Keywords:}

Titanium dioxide

Carbon doping

Surface carbonaceous species

4-Chlorophenol

Photodegradation

Synergistic effect

\begin{abstract}
A B S T R A C T
Visible light-sensitive carbon doped titanium dioxide $\left(\mathrm{C}-\mathrm{TiO}_{2}\right)$ was prepared by grinding anatase $\mathrm{TiO}_{2}$ with anhydrous D-glucose solution as carbon source followed by calcination. The catalysts were characterized by X-ray diffraction (XRD), X-ray photoelectron spectroscopy (XPS), BET surface area measurements, scanning electron microscopy (SEM), diffuse reflectance spectroscopy (DRS), FTIR analysis and photoluminescence (PL) techniques. The results confirmed the interstitial incorporation of carbon atoms in the $\mathrm{TiO}_{2}$ lattice via $\mathrm{O}-\mathrm{Ti}-\mathrm{C}$ and $\mathrm{Ti}-\mathrm{O}-\mathrm{C}$ surface states. The calculation of valence band (VB) edge position of $\mathrm{C}-\mathrm{TiO}_{2}$ by using electronegativity values shows cathodic shift with increase in the carbon concentration and this renders high oxidative power for photogenerated holes. The observed new electronic state above the VB edge was responsible for the electronic origin of band gap narrowing and visible light photoactivity of C$\mathrm{TiO}_{2}$. The carbon atom was also present as carbonaceous species on the surface which acts as sensitizer. The photocatalytic activity of $\mathrm{C}-\mathrm{TiO}_{2}$ was evaluated for the degradation of 4-chlorophenol under both UV and solar irradiation. The undoped $\mathrm{TiO}_{2}$ showed better activity under UV light whereas $\mathrm{C}_{-} \mathrm{TiO}_{2}$ showed higher photocatalytic activity under visible light. The pretreatment of $\mathrm{C}-\mathrm{TiO}_{2}$ with $\mathrm{UV}$ light reduced the visible light activity due to the removal of surface carbonaceous species. The synergistic effect of surface carbonaceous species along with interstitial carbon is discussed in detail and accounted for visible light activity.
\end{abstract}

(c) 2014 Elsevier Ltd. All rights reserved.

\section{Introduction}

Titania has been regarded as the most promising photocatalyst due to its ability to completely mineralize the pollutants without other derivative chemicals. $\mathrm{TiO}_{2}$ has attracted much attention due to unique optical and electronic properties which makes it suitable for the oxidation of organic pollutants [1]. The band gap excitation of titania under UV light promotes the transfer of electron from valence band (VB) to conduction band (CB). The photogenerated electrons and holes may take part in subsequent redox reactions with various ions/molecules adsorbed on the photocatalyst surface. The large band gap of $\mathrm{TiO}_{2}(3.2 \mathrm{eV})$ and high degree of charge carrier recombination impair its practical applications under natural solar light [2,3]. The effective approach to tackle this challenge is to dope or co-dope $\mathrm{TiO}_{2}$ with nonmetal elements such as C, N, S, I, B, P and F to extend the light absorbance of $\mathrm{TiO}_{2}$ into visible region [4-6]. Among these dopants, carbon has received prominent importance. The visible light absorption in nonmetal doped titania is attributed to the incorporation of non-metal ion into $\mathrm{TiO}_{2}$ lattice (i.e., doping) and also to the formation

\footnotetext{
* Corresponding author.

E-mail address: gomatidevi_naik@yahoo.co.in (L.G. Devi).
}

of chromophoric complexes at the surface (i.e., sensitization) formed by non-metal dopant source. Kisch et al. reported surface modification and interfacial sensitization mechanism by calcining $\mathrm{TiO}_{2}$ in presence of urea [7]. Based on First Principle Calculations, it was shown that the carbon atom could replace either oxygen or titanium in the titania lattice depending on the concentration of oxygen present during the preparation process [8]. The carbon doping facilitates charge transfer process from bulk $\mathrm{TiO}_{2}$ to the surface region via improving the extent of adsorption of organic pollutant molecules on the catalyst surface and increasing the conductivity of titania [9]. The formal oxidation state of carbon dopant ranges from -4 (carbides with $\mathrm{Ti}-\mathrm{C}$ bond) to +4 (carbonates with $\mathrm{C}-\mathrm{O}$ bond) [8]. In the present work, we report the synthesis of carbon doped $\mathrm{TiO}_{2}\left(\mathrm{C}-\mathrm{TiO}_{2}\right)$, and its photocatalytic activity was evaluated for the decomposition of 4-CP under UV/solar light irradiation.

\section{Experimental}

\section{Materials}

The $\mathrm{TiCl}_{4} \geq 99.9 \%$ was obtained from Merck Chemicals, while anhydrous D-glucose $\left(\mathrm{C}_{6} \mathrm{H}_{12} \mathrm{O}_{6}\right)$ and 4-chlorophenol (4-CP) were supplied from SD Fine Chemicals, Bombay. 


\section{Catalyst preparation}

Anatase form of $\mathrm{TiO}_{2}$ was synthesized by sol-gel route through the hydrolysis of $\mathrm{TiCl}_{4}$ [10]. In a typical procedure, $25 \mathrm{~mL}$ of diluted $\mathrm{TiCl}_{4}$ (100 mL of concentrated $\mathrm{TiCl}_{4}$ was diluted to $1 \mathrm{~L}$ ) with $1 \mathrm{~mL}$ concentrated $\mathrm{H}_{2} \mathrm{SO}_{4}$ was taken in a beaker and diluted to1 L. The solution $\mathrm{pH}$ was increased to $7-8$ by the addition of liquor ammonia. The titanium hydroxide gel obtained is washed several times with double distilled water to make it free from chloride and ammonium ions. The gel was filtered, dried in an oven to remove adsorbed water molecules and then ground to a fine powder and it was calcined at $600{ }^{\circ} \mathrm{C}$ for $6 \mathrm{~h}$. For the preparation of $0.04 \mathrm{wt} \% \mathrm{C}-\mathrm{TiO}_{2}, 0.00902 \mathrm{~g}$ of anhydrous D-glucose was dissolved in $25 \mathrm{~mL}$ double distilled water. Then, $2.5 \mathrm{~mL}$ of this solution is added to $1 \mathrm{~g}$ of $\mathrm{TiO}_{2}$ and this mixture was ground in a pestle and mortar. The process of grinding is repeated for four times and the powder is finally calcined at $200^{\circ} \mathrm{C}$ for $1 \mathrm{~h}$ to get $\mathrm{C}-\mathrm{TiO}_{2}$. Similar method was adopted for the preparation of $\mathrm{C}-\mathrm{TiO}_{2}$ with various dopant concentrations. The samples with $0.06,0.08$ and $0.1 \mathrm{wt} \%$ were abbreviated as $\mathrm{C}^{-\mathrm{TiO}_{2}}$ (0.06 wt\%), $\mathrm{C}-\mathrm{TiO}_{2}$ (0.08 wt\%) and $\mathrm{C}-\mathrm{TiO}_{2}(0.1 \mathrm{wt} \%)$ respectively. With increase in the calcination temperature from 250 to $400{ }^{\circ} \mathrm{C}$, the color of the samples turned white implicating the complete removal of carbon from $\mathrm{TiO}_{2}$ lattice [11]. In order to confirm the role of surface carbon, the prepared C$\mathrm{TiO}_{2}$ sample was subjected to UV illumination for $1 \mathrm{~h}$. The color of the $\mathrm{C}-\mathrm{TiO}_{2}$ changed from dark brown to light brown suggesting the elimination of only surface carbon under UV illumination and this catalyst is abbreviated as UV pretreated $\mathrm{C}-\mathrm{TiO}_{2}$ samples.

\section{Catalyst characterization}

The powder X-ray diffraction (PXRD) patterns were obtained using Bruker D8 Advanced diffractometer, which was operated at 30 $\mathrm{kV}$ and $20 \mathrm{~mA}$ using $\mathrm{Cu} \mathrm{K} \alpha$ with nickel filter. The scan rate was varied from $2^{\circ}$ to $0.5^{\circ} / \mathrm{min}$ to get X-ray diffraction line broadening. The Fourier transform infra red (FTIR) spectra were obtained using Bruker model Alpha-P IR spectrometer with diamond ATR cell. The X-ray photoelectron spectroscopy (XPS) measurements were carried out using AXIS ULTRA from AXIS 165, integrated with Kratos patented magnetic immersion lens along with charge neutralization system and spherical mirror analyzer. All binding energies were calibrated with respect to the carbon $1 \mathrm{~s}$ peak at $284.8 \mathrm{eV}$. The diffuse reflectance spectra (DRS) were obtained using UV-vis spectrophotometer (Schimadzu-UV 3101 PC UV-vis-NIR) with $\mathrm{BaSO}_{4}$ as the reference standard. The absorbance data were transformed into reflectance values and Kubelka-Munk method is used for the band gap measurement. The surface morphology was analyzed by scanning electron microscopy (SEM) analysis using JSM840 microscope operating at 25 $\mathrm{kV}$ on specimen upon which a thin layer of platinum had been evaporated. The nitrogen adsorption-desorption isotherms were recorded on a Nova Quanta Chrome Corporation 2006 Digisorb analyzer at liquid nitrogen temperature $77 \mathrm{~K}$. The samples were degassed at 200 ${ }^{\circ} \mathrm{C}$ overnight prior to the measurement. The surface area was obtained by Brunner-Emmet-Teller (BET) method and pore size distribution was calculated from the adsorption branch of the isotherm by the Barret-Joyner-Halenda (BJH) model. The photoluminescence (PL) spectra were measured on a Hitachi F-7000 fluorescence spectrophotometer. The reaction intermediates during the course of degradation reaction were analyzed from GC-MS technique using Thermo Trace GC Ultr, MS model Thermo DSQ II with electron impact ionisation and the chemical ionisation with mass range $1-1071 \mathrm{~m} / \mathrm{z}$.

\section{Photochemical reactor}

Experiments were carried out at room temperature using a circular glass reactor whose surface area is $176.6 \mathrm{~cm}^{2}$, using $125 \mathrm{~W}$ medium pressure mercury vapor lamp as the UV light source. The photon flux was found to be $7.8 \mathrm{~mW} / \mathrm{cm}^{2}$ by ferrioxalate actinometric method [12]. The emission wavelength falls in the region 350-400 nm, with maximum emission at $370 \mathrm{~nm}$. No additional step was taken to eliminate the light of different wavelengths, since this process reduces the intensity of light. The irradiation was carried out by directly focusing light into the reaction mixture in the open air condition at a distance of $29 \mathrm{~cm}$. All the experiments were performed using double distilled water. Solar light experiments were performed under sunlight directly between 11 a.m. and 2 p.m. when the solar intensity fluctuations were minimal and sunrays were not oblique. The experiments were conducted in the month of April-May at Bangalore, India. The latitude and longitude are $12.58 \mathrm{~N}$ and $77.38 \mathrm{E}$ respectively. The average solar intensity was found to be $0.753 \mathrm{~kW} / \mathrm{m}^{2}$ (using solar radiometer). The intensity of the solar light was concentrated by using a convex lens and the reaction mixture was exposed to this concentrated sunlight. The solar radiation as a function of wavelength was measured by photometer, which shows a maximum at $450 \mathrm{~nm}$. To compare the photocatalytic activity of all the catalysts, experiments were simultaneously conducted to avoid the error arising due to the fluctuations in solar intensity. A typical experiment contains $60 \mathrm{mg}$ of photocatalyst dispersed in $250 \mathrm{~mL}$ of $10 \mathrm{ppm} 4-\mathrm{CP}$ solution. The reaction mixture was stirred vigorously using magnetic stirrer for entire time span of the experiment. Prior to irradiation, the reaction mixture was stirred for $30 \mathrm{~min}$ to ensure the establishment of adsorption/ desorption equilibrium. The extent of adsorption is found from the equation; $Q=\left(C_{0}-C\right) V / W$, where $Q$ is the extent of adsorption, $C_{0}$ and $C$ are the concentrations before and after adsorption, $V$ is the volume of the reaction mixture and $W$ is the amount of catalyst present in grams. The unit of $Q$ is ppm $\mathrm{mL} \mathrm{mg}^{-1}$. Thirty minutes time period is selected as time to achieve a steady state adsorption level for 4-CP. The extent of adsorption did not change for prolonged time period. The $5 \mathrm{~mL}$ aliquots were collected from the suspension at definite time intervals and immediately centrifuged and filtered through $0.45 \mu \mathrm{m}$ Millipore filter to remove the catalyst particles for spectrophotometric analysis. The residual concentration of 4-CP was determined by UV-vis spectrophotometer. A blank experiment containing only the pollutant 4-CP in the absence of photocatalyst under UV illumination was performed in order to determine the contribution of direct photolysis. The experimental results confirmed the absence of contribution from direct photolysis.

\section{Results and discussion}

\section{PXRD studies}

The $\mathrm{TiO}_{2}$ was obtained by sol-gel technique in the present study. Anatase phase was found to be stable up to $600^{\circ} \mathrm{C}$, but further rise in temperature to $700{ }^{\circ} \mathrm{C}$ rutile phase formation takes place. During the calcination process around $450{ }^{\circ} \mathrm{C}$ the water content in the sample is completely eliminated and the crystallinity of the sample sets in and stabilizes in the temperature range of $450-550{ }^{\circ} \mathrm{C}$ and hence the sample was heated to $550-600{ }^{\circ} \mathrm{C}$ [10]. The diffraction peaks for $\mathrm{TiO}_{2}$ and $\mathrm{C}-\mathrm{TiO}_{2}$ (with various carbon dopant concentrations) and the sample heat treated at $200{ }^{\circ} \mathrm{C}$ confirmed the anatase polymorph (Fig. $1)$. The average crystallite size was estimated based on broadening of $\left(\begin{array}{lll}1 & 0 & 1\end{array}\right)$ peak using the Scherrer's equation (1) and lattice strain $(\epsilon)$ was calculated from Eq. (2).

$D=\frac{k \lambda}{\beta \cos \theta}$

$\varepsilon=\frac{\beta}{4 \tan \theta}$

where $\lambda$ is the wavelength of $\mathrm{Cu} K \alpha$ source used, $\beta$ is full width at half maximum (FWHM) of ( 101 ) diffraction plane, $k$ is a shape factor (0.94) and $\theta$ is angle of diffraction. The X-ray diffraction peaks of crystal planes (200) and (20 4) of anatase were selected to determine 


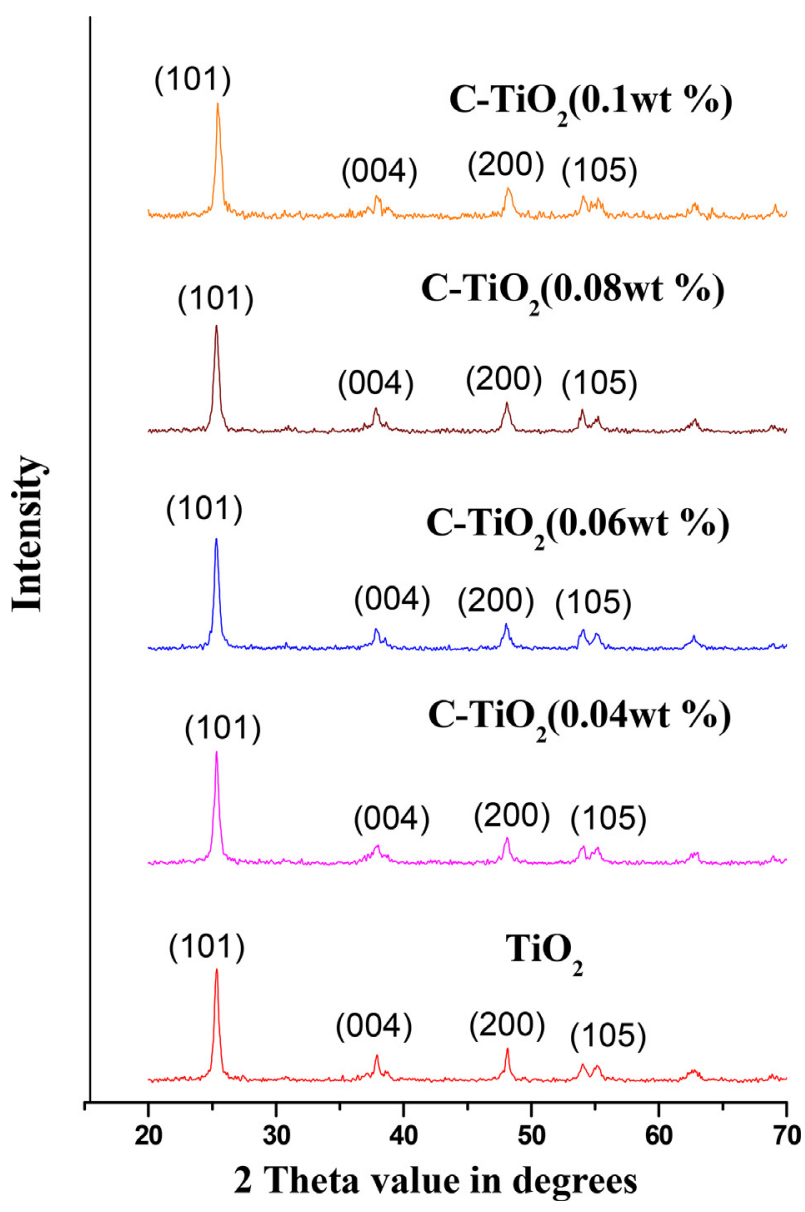

Fig. 1. XRD patterns of $\mathrm{TiO}_{2}$ and $\mathrm{C}-\mathrm{TiO}_{2}$ photocatalysts with various dopant concentrations.

lattice parameters of doped samples using (Eqs. (3) and (4)):

$d_{h k l}=\frac{\lambda}{2 \sin \theta}$

$\frac{1}{d_{h k l}^{2}}=\frac{h^{2}}{a^{2}}+\frac{k^{2}}{b^{2}}+\frac{l^{2}}{c^{2}}$

$d_{h k l}$ is the distance between crystal planes of $(h k l), \lambda$ is X-ray wavelength, $\theta$ is diffraction angle of crystal plane $(h k l)$ and $a, b, c$ are the lattice parameters. The calculated values of crystallite size, lattice parameters, cell volume and lattice strain for $\mathrm{TiO}_{2}$ and $\mathrm{C}-\mathrm{TiO}_{2}$ samples are given in Table 1. It could be observed that incorporation of carbon atoms inhibits the crystal growth of $\mathrm{TiO}_{2}$. The crystallite size decreased with increase in carbon dopant concentration and it was found to be $12.14 \mathrm{~nm}$ for $\mathrm{C}-\mathrm{TiO}_{2}(0.1 \mathrm{wt} \%)$. Cell volume and lattice strain increase with an increase in carbon concentration.

\section{XPS studies}

The chemical state of carbon dopant in $\mathrm{C}-\mathrm{TiO}_{2}$ (0.04 wt\%) sample was analyzed by XPS technique and it confirms the presence of only $\mathrm{Ti}, \mathrm{O}$ and $\mathrm{C}$ atoms (Fig. S1). The binding energy (BE) peak values of $\mathrm{Ti}$ $2 \mathrm{p}_{3 / 2}$ and $\mathrm{Ti} 2 \mathrm{p}_{1 / 2}$ of $\mathrm{TiO}_{2}$ were observed at $459.50 \mathrm{eV}$ and $465.35 \mathrm{eV}$ respectively (Fig. 2a). These peaks were found at $459.35 \mathrm{eV}$ and 465.31 $\mathrm{eV}$ for $\mathrm{C}-\mathrm{TiO}_{2}$ (0.04 wt\%). A small positive shift of binding energy of $\mathrm{Ti} 2 \mathrm{p}$ for the doped samples by $0.15 \mathrm{eV}$ in comparison with $\mathrm{TiO}_{2}$ is predicted due to the presence of interstitial carbon in $\mathrm{TiO}_{2}$ lattice and it could be specifically accounted for the decrease of electron cloud density around $\mathrm{Ti}^{4+}$ ion upon carbon doping. The XPS spectra of the
Table 1

PXRD details of $\mathrm{TiO}_{2}$ and $\mathrm{C}-\mathrm{TiO}_{2}$ photocatalyst.

\begin{tabular}{|c|c|c|c|c|}
\hline Photocatalyst & $\begin{array}{l}\text { Crystallite } \\
\text { size }(\mathrm{nm})\end{array}$ & $\begin{array}{l}\text { Lattice } \\
\text { parameters } \\
(\AA)\end{array}$ & $\begin{array}{l}\text { Cell volume } \\
\left(\AA^{3}\right)\end{array}$ & $\begin{array}{l}\text { Lattice strain } \\
\left(10^{-3}\right)\end{array}$ \\
\hline $\mathrm{TiO}_{2}$ & 18.87 & $\begin{array}{l}a=b= \\
3.7770 \\
c=9.4213\end{array}$ & 134.40 & 9.2603 \\
\hline $\begin{array}{l}\mathrm{C}-\mathrm{TiO}_{2} \\
(0.04 \mathrm{wt} \%)\end{array}$ & 17.38 & $\begin{array}{l}a=b= \\
3.7773 \\
c=9.4427\end{array}$ & 134.72 & 10.1038 \\
\hline $\begin{array}{l}\mathrm{C}-\mathrm{TiO}_{2} \\
(0.06 \mathrm{wt} \%)\end{array}$ & 16.29 & $\begin{array}{l}a=b= \\
3.7802, \\
c=9.4640\end{array}$ & 135.23 & 10.7729 \\
\hline $\begin{array}{l}\mathrm{C}-\mathrm{TiO}_{2} \\
(0.08 \mathrm{wt} \%)\end{array}$ & 13.76 & $\begin{array}{l}a=b= \\
3.7847 \\
c=9.4892\end{array}$ & 135.92 & 12.7794 \\
\hline $\begin{array}{l}\mathrm{C}-\mathrm{TiO}_{2}(0.1 \\
\mathrm{wt} \%)\end{array}$ & 12.41 & $\begin{array}{l}a=b= \\
3.7922, \\
c=9.5100\end{array}$ & 136.76 & 14.1077 \\
\hline
\end{tabular}

O1s region consist of three peaks (Fig. 2b). The peak located at $530 \mathrm{eV}$ is related to oxygen bonded to $\mathrm{Ti}$ as $\mathrm{Ti}-\mathrm{O}$ and other small intensity peak at $531 \mathrm{eV}$ can be assigned to the surface adsorbed hydroxyl groups/water molecules $[13,14]$. The low intensity peaks at $\sim 532.9$ and $533 \mathrm{eV}$ can be assigned to the oxygen in the $\mathrm{Ti}-\mathrm{O}-\mathrm{C}$ bond [15]. The $\mathrm{BE}$ peaks corresponding to $\mathrm{C} 1 \mathrm{~s}$ of $\mathrm{C}-\mathrm{TiO}_{2}$ were observed at 285.4 , 286, 287.4 and $289 \mathrm{eV}$ (Fig. 2c). The low intensity BE peaks at 286, 287.4 and 289 indicate the presence of $\mathrm{C}-\mathrm{O}, \mathrm{C}=\mathrm{O}$ and interstitial carbon in the $\mathrm{TiO}_{2}$ lattice respectively $[14,16]$. The carbon atom being bonded to two electronegative oxygen atoms, experiences more of its electron density pulled towards the oxygen atoms. The BE peak at $289 \mathrm{eV}$ confirms the presence of carbon in the interstitial position into $\mathrm{TiO}_{2}$ lattice and further the absence of BE peak at $282 \mathrm{eV}$ confirms the absence of carbon in substitutional lattice position. The above results are in accordance with the literature reports obtained from Kisch et al. showing two kinds of carbonate species with binding energies of 287.5 and $288.5 \mathrm{eV} \mathrm{[17].} \mathrm{Kim} \mathrm{et} \mathrm{al.} \mathrm{have} \mathrm{also} \mathrm{reported} \mathrm{carbonate}$ species in their carbon-doped $\mathrm{TiO}_{2}$ samples at the $\mathrm{BE}$ of $288.2 \mathrm{eV}$ [18]. These results suggest that the chemical nature of the "carbon dopant" in $\mathrm{TiO}_{2}$ lattice at interstitial position and also its presence at the surface.

\section{DRS studies}

The results obtained by DRS studies are used to investigate the electronic band structure of $\mathrm{TiO}_{2}$. The band gap energy $\left(E_{\mathrm{g}}\right)$ of each catalyst was determined by using Kubelka-Munk function. The intercepts of the tangents to the plots of $\left[F\left(R_{\infty}\right) h v\right]^{\frac{1}{2}}$ versus photon energy $(h v)$ are shown in Fig. 3. The Kubelka-Munk function $F\left(R_{\infty}\right)$ and photon energy $(h v)$ can be calculated by following (Eqs. (5)-(7)) [19,20]:

$F\left(R_{\infty}\right)=\frac{\left(1-R_{\infty}\right)^{2}}{2 R_{\infty}}$

$R_{\infty}=10^{-A}$

$h v=\frac{1240}{\lambda}$

where $R_{\infty}$ is reflection coefficient of the sample, $A$ is absorbance intensity of $\mathrm{TiO}_{2}$ and $\lambda$ is absorption wavelength. The undoped $\mathrm{TiO}_{2}$ shows optical absorption threshold at $393 \mathrm{~nm}$ corresponding to band gap of $3.15 \mathrm{eV}$ and no absorption edge was observed in the visible region (Table 2). All $\mathrm{C}-\mathrm{TiO}_{2}$ samples showed band gap narrowing compared to $\mathrm{TiO}_{2}$ which is attributed to the formation of interstitial carbon dopant level resulting in the cathodic shift of energy levels. The extension of absorption in visible region with increase in carbon 


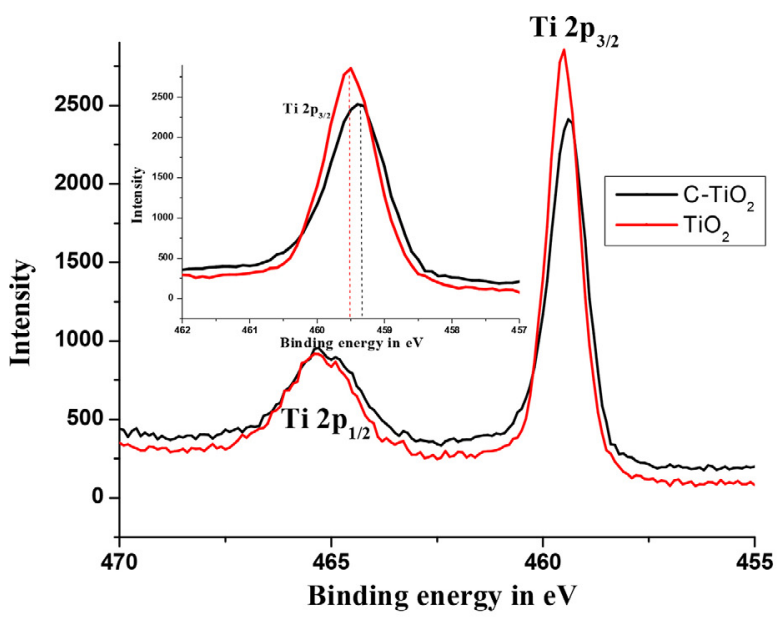

(a)

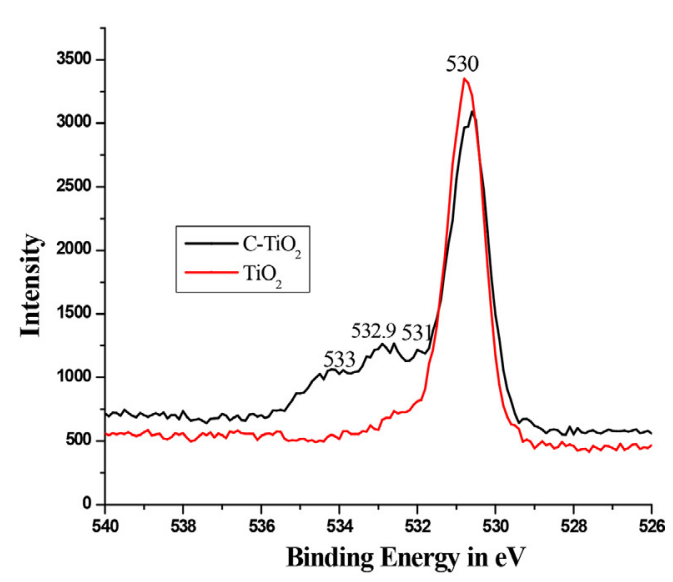

(b)

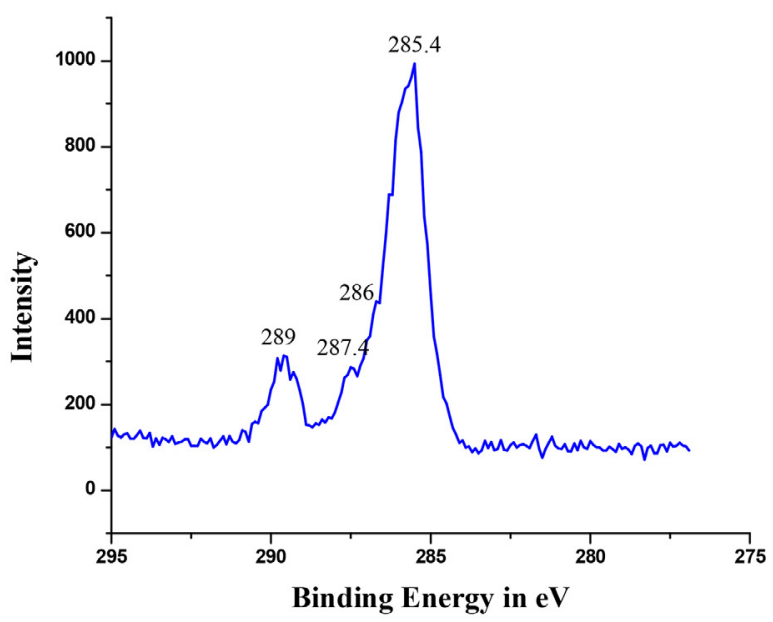

(c)

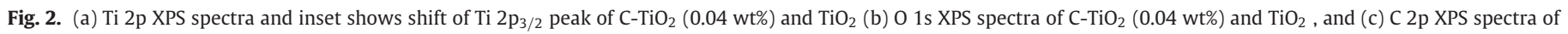
$\mathrm{C}-\mathrm{TiO}_{2}(0.04 \mathrm{wt} \%)$.

content was due to the formation of chemical bonding between carbon and titanium or oxygen through $\mathrm{O}-\mathrm{Ti}-\mathrm{C}$ and $\mathrm{Ti}-\mathrm{O}-\mathrm{C}$ bonds [21]. The band gap energy was reduced from 3.15 to $2.83 \mathrm{eV}$ for high dopant concentration $(0.1 \mathrm{wt} \%)$. The absorption tailing in the visible region can also be attributed to the existence of carbonaceous species on the titania surface.

\section{Calculations of $\mathrm{VB}$ edge positions of $\mathrm{C}-\mathrm{TiO}_{2}$}

The ability of a semiconductor to transfer the photogenerated charge carriers to species adsorbed on its surface is governed by the band edge positions of semiconductor and the redox potentials of the adsorbate, which in turn is related to their electronegativity values [22]. The semiconductor electronegativity is defined as geometric mean of electronegativities of the constituent atoms is explained as follows:

$\chi=\sqrt[N]{\chi_{1}^{n} \chi_{1}^{s} \ldots \ldots \chi_{n-1}^{p} \chi_{n}^{q}}$

where $\chi$ is total electronegativity value of the semiconductor. $\chi^{n}, n$ and $N$ are the electronegativity of the constituent atom, the number of species and total number of atoms in the compound, respectively. Electronegativity is of great significance in band gap structure which

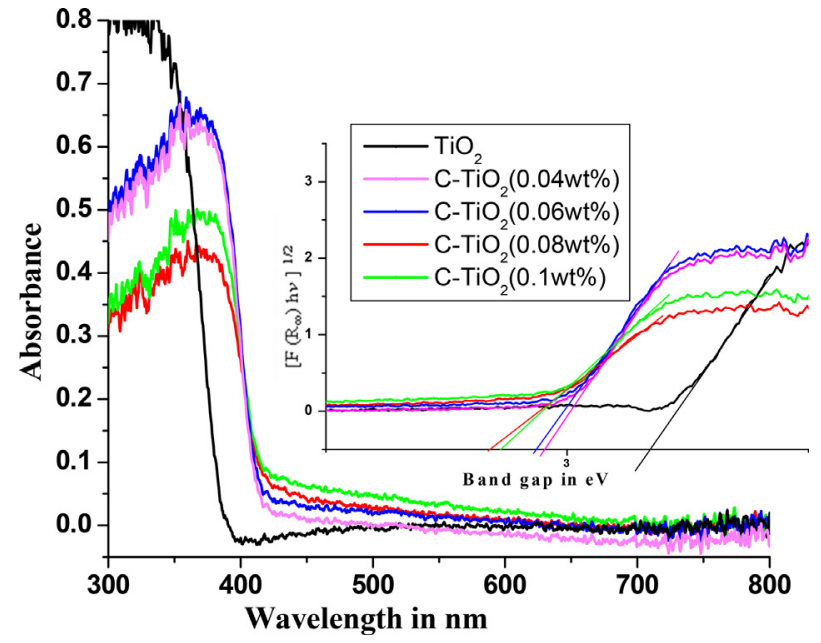

Fig. 3. UV-vis diffuse reflectance spectra of $\mathrm{TiO}_{2}$ and $\mathrm{C}-\mathrm{TiO}_{2}$ photocatalysts. The inset shows plots of $\left[F\left(R_{\infty}\right) h v\right]^{\frac{1}{2}}$ versus photon energy $(h v)$ for $\mathrm{TiO}_{2}$ and $\mathrm{C}-\mathrm{TiO}_{2}$ photocatalysts. 
Table 2

Summary of calculated conduction band edge position, extension of valence band position on doping and band gap energy values for $\mathrm{TiO}_{2}$ and $\mathrm{C}^{-\mathrm{TiO}_{2}}$ photocatalysts.

\begin{tabular}{|c|c|c|c|}
\hline Photocatalyst & $\begin{array}{l}\text { Calculated conduction band position } \\
(\mathrm{eV})\end{array}$ & Calculated valence band position (eV) & Band gap energy (eV) \\
\hline $\mathrm{TiO}_{2}$ & -0.235 & 2.915 & 3.15 \\
\hline $\mathrm{C}-\mathrm{TiO}_{2}(0.04 \mathrm{wt} \%)$ & -0.235 & 2.705 & 2.95 \\
\hline $\mathrm{C}-\mathrm{TiO}_{2}(0.06 \mathrm{wt} \%)$ & -0.235 & 2.684 & 2.93 \\
\hline $\mathrm{C}-\mathrm{TiO}_{2}(0.08 \mathrm{wt} \%)$ & -0.235 & 2.625 & 2.86 \\
\hline $\mathrm{C}-\mathrm{TiO}_{2}(0.1 \mathrm{wt} \%)$ & -0.235 & 2.595 & 2.83 \\
\hline
\end{tabular}

determines the relative positions of impurity levels induced by doping and influences the optical absorption and photocatalytic activity of $\mathrm{TiO}_{2}$. The impurity states move further away from the VB with the increment of electronegativity difference between substituted element and oxygen [23]. The band edge positions of $\mathrm{CB}$ and $\mathrm{VB}$ of all the semiconductor samples were determined in the following way:

$E_{\mathrm{CB}}^{0}=\chi-E^{\mathrm{e}}-\frac{1}{2} E_{\mathrm{g}}$

The $E^{0}$ in the above equation refers to the position of $\mathrm{CB}$ edge of $\mathrm{TiO}_{2}$ at the isoelectric point (when $\mathrm{TiO}_{2}$ is amphoteric), while $E^{\mathrm{e}}$ refers to the energy of free electron with respect to the standard hydrogen scale $(4.5 \mathrm{eV})$ [24]. The absolute electronegativity $\chi=5.84 \mathrm{eV}$ for $\mathrm{TiO}_{2}$ is calculated from Eq. (8), while $E_{\mathrm{g}}$ is the band gap energy of the semiconductor calculated from Kubelka-Munk function. The CB edge position of all the samples remains the same irrespective of the carbon dopant concentration, whereas the VB edge position varies with dopant concentration. The calculated band edge positions of $\mathrm{TiO}_{2}$ and $\mathrm{C}-\mathrm{TiO}_{2}$ samples are listed in Table 2 . Thus, the band edge position of $\mathrm{VB}$ for $\mathrm{C}-\mathrm{TiO}_{2}$ can be calculated by the difference between the calculated values of $\mathrm{CB}$ edge position of $\mathrm{TiO}_{2}$ and indirect band gap of $\mathrm{C}-\mathrm{TiO}_{2}$.

\section{FTIR studies}

The FTIR studies revealed a broad peak around $3400 \mathrm{~cm}^{-1}$ and a sharp peak at $1630 \mathrm{~cm}^{-1}$ originating from surface absorbed water and hydroxyl groups which are invariantly present on the surface of transition metal oxides (Fig. 4) and conventionally considered as an important factor in affecting surface properties of the metal oxide [25]. The spectrum shows a relatively strong band at $1630 \mathrm{~cm}^{-1}$ attributed to $\mathrm{H}-\mathrm{O}-\mathrm{H}$ bending vibration of chemisorbed/physisorbed $\mathrm{H}_{2} \mathrm{O}$ molecule on the both $\mathrm{TiO}_{2}$ and $\mathrm{C}-\mathrm{TiO}_{2}$ surface. The peak intensity around $3200 \mathrm{~cm}^{-1}$ decreases for $\mathrm{C}-\mathrm{TiO}_{2}$ (0.04 wt\%) sample compared to $\mathrm{TiO}_{2}$ as the surface carbonaceous species changes the surface nature of $\mathrm{TiO}_{2}$. The intensity of $1630 \mathrm{~cm}^{-1}$ peak is almost similar for all the doped samples up to $\mathrm{C}-\mathrm{TiO}_{2}(0.08 \mathrm{wt} \%)$ as the surface is covered by dominant carbonaceous species and the concentration of adsorbed water or hydroxyl groups vary accordingly. Quantitative estimation of surface hydroxyl groups based on the IR peak intensities is rather speculative at times. In addition, existence of surface carbonaceous species was identified from a distinct peak at $1423 \mathrm{~cm}^{-1}$. The peaks around the region $660 \mathrm{~cm}^{-1}$ may be attributed to $\mathrm{C}-\mathrm{H}$ (bending vibrations), $\mathrm{C}-\mathrm{C}$, and $\mathrm{C}-\mathrm{O}$ functional groups [26]. The IR bands in the region $400-1000 \mathrm{~cm}^{-1}$ are highly sensitive to changes in $\mathrm{Ti}-\mathrm{O}-\mathrm{Ti}$ bond environment. The characteristic peaks around 420 and $600 \mathrm{~cm}^{-1}$ are assigned for $\mathrm{Ti}-\mathrm{O}$ bond stretching vibration of $\mathrm{TiO}_{2}$. Stretching of $\mathrm{Ti}-\mathrm{O}-\mathrm{Ti}$ bonds may give rise to absorption bands between 500 and $900 \mathrm{~cm}^{-1}$ and the stretching of terminal $\mathrm{Ti}-\mathrm{O}$ bonds in $\mathrm{TiO}_{2}$ clusters is observed between 990 and $1033 \mathrm{~cm}^{-1}$ [26].

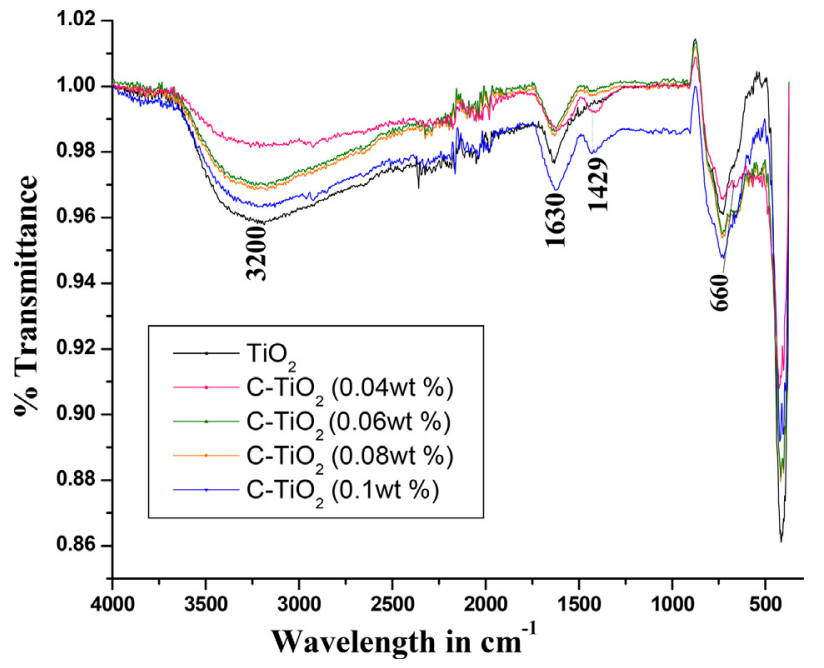

Fig. 4. FTIR spectra of $\mathrm{TiO}_{2}$ and $\mathrm{C}-\mathrm{TiO}_{2}$ photocatalysts.

\section{SEM analysis}

The SEM images show significant differences in surface morphology between the pure $\mathrm{TiO}_{2}$ and $\mathrm{C}-\mathrm{TiO}_{2}$ samples (Fig. 5). The morphology of all the $\mathrm{C}-\mathrm{TiO}_{2}$ samples was almost similar and hence SEM image of $\mathrm{C}-\mathrm{TiO}_{2}(0.04 \mathrm{wt} \%)$ alone is given. The morphology of $\mathrm{C}-\mathrm{TiO}_{2}$ shows a multisphere-like structure. The observed decrease in the particle size contributes to the increase in the surface area of the doped samples.

\section{BET studies}

The nitrogen adsorption-desorption isotherm and the inset of the figure shows the pore size distribution curve of $\mathrm{TiO}_{2}$ and $\mathrm{C}-\mathrm{TiO}_{2}$ samples (Fig. 6). The pore size distribution was calculated from desorption branch of a nitrogen isotherm by the BJH method. All samples exhibited typically characteristic mesoporous structure, which was confirmed by $\mathrm{N}_{2}$ gas sorption which shows type - IV adsorption isotherm with an elongated S-type hysteresis loop. The occurrence of hysteresis due to capillary condensation is observed at relatively low pressure for the doped samples compared to pristine $\mathrm{TiO}_{2}$. The hysteresis nature implies that the doped samples have a mesoporous structure with a narrow pore size distribution at the top and with a wider size at the bottom. The degree of agglomeration (DA) can be calculated by using BET data with the following formula [27];

$\mathrm{DA}=\frac{D_{\mathrm{BET}}}{D_{\mathrm{XRD}}}$

$D_{\text {BET }}$ is the average particle size in nanometer calculated from BET surface area and $D_{\text {XRD }}$ is the XRD crystallite size as obtained from the Scherrer's equation data respectively. The approximate $D_{\mathrm{BET}}$ value is calculated from Eq. (10) assuming that all particles to have same spherical shape and size, the shape factor for a sphere is assumed as 

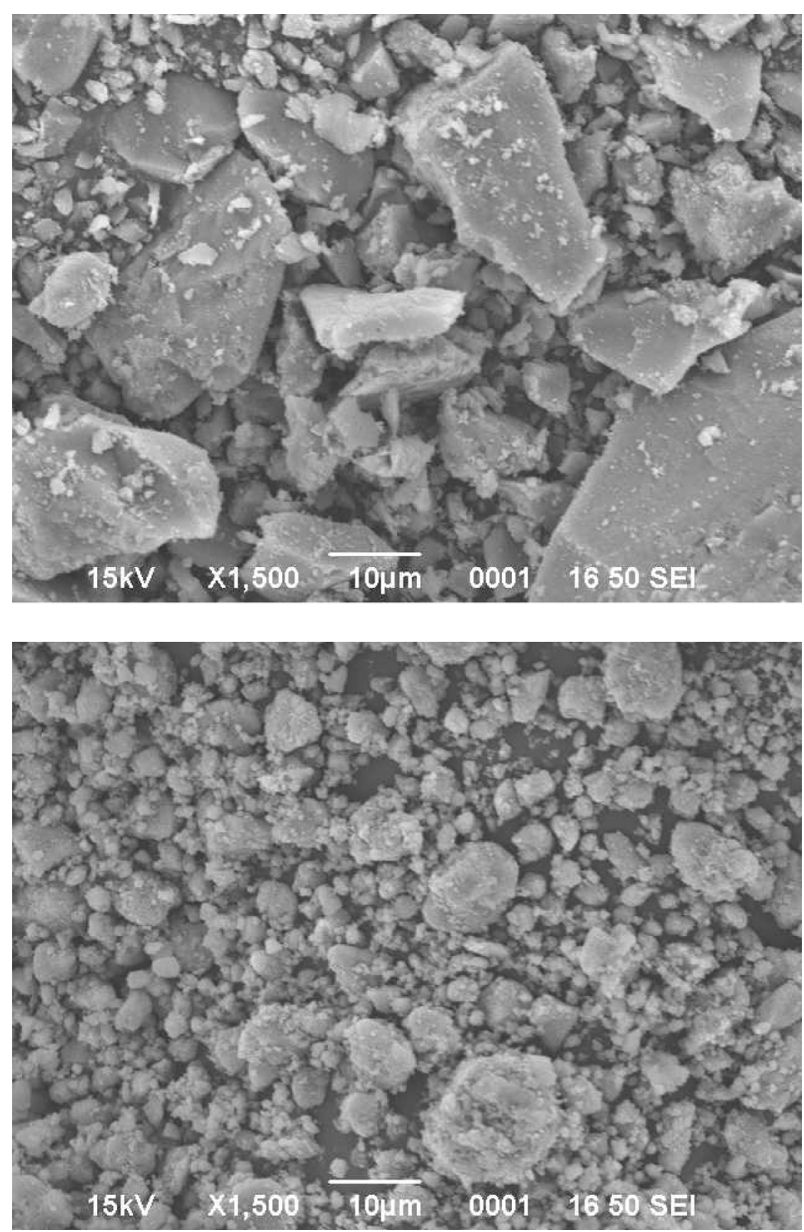

Fig. 5. SEM images of $\mathrm{TiO}_{2}$ (top) and $\mathrm{C}-\mathrm{TiO}_{2}(0.04 \mathrm{wt} \%)$ (bottom) photocatalysts.

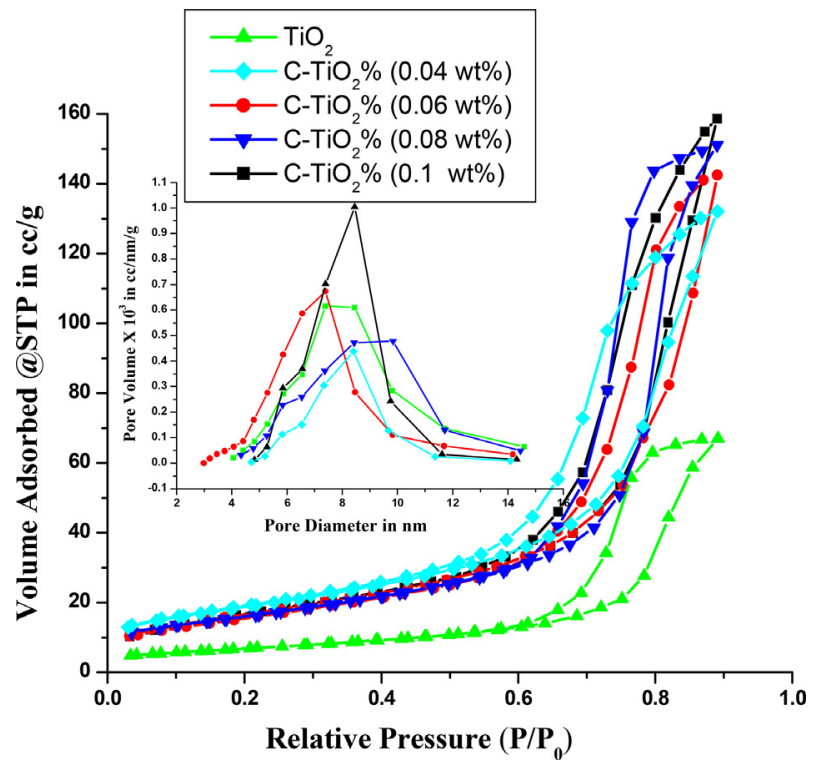

Fig. 6. The $\mathrm{N}_{2}$ adsorption-desorption isotherms of $\mathrm{TiO}_{2}$ and $\mathrm{C}-\mathrm{TiO}_{2}$ photocatalysts. The figure inset shows $\mathrm{BJH}$ pore size distribution curve of $\mathrm{TiO}_{2}$ and $\mathrm{C}-\mathrm{TiO}_{2}$ photocatalysts.

6000 and the value of $D_{\mathrm{BET}}$ is calculated in the following way: [27,28]

$D_{\text {BET }}=\frac{6000}{\rho \times \text { BET surface area }}$

$\rho=\mathrm{ZM} / \mathrm{VN}_{\mathrm{A}}=3.89 \mathrm{~g} / \mathrm{cm}^{3}$, where $\rho$ is the density of anatase phase,
$Z$ is the number of formula units per unit cell (for $\mathrm{TiO}_{2} Z=2$ ), $M$ is the formula weight in the unit cell (for $\mathrm{TiO}_{2}, M=159.76 \mathrm{~g} / \mathrm{mol}$ ), $V$ is the cell volume of $\mathrm{TiO}_{2}\left(134.40 \times 10^{-23} \mathrm{~cm}^{3}\right)$, and $N_{\mathrm{A}}$ is Avogadro number $\left(6.022 \times 10^{23} \mathrm{~mol}^{-1}\right)$. DA influences many factors including adsorption of molecules, light scattering and photon absorption, charge carrier dynamics, etc. The DA is very low for all the C-TiO 2 samples due to the stabilization provided by the surface charges induced by carbonaceous species [29]. The values of various parameters such as BET surface area, pore diameter, pore volume, particle size and the extent of DA of all the samples are summarized in Table 3. It can be seen that the values of BET surface area and pore volume of $\mathrm{C}-\mathrm{TiO}_{2}$ samples are higher than undoped $\mathrm{TiO}_{2}$. The carbon gets substituted at interstitial sites and it is also distributed on the surface of titania. The doped carbon atoms segregate near the grain boundaries and it inhibits the grain growth by providing a barrier between the titania particles and restricts their direct contact [30]. On the other hand, surface carbon prevents the aggregation of titania by avoiding the interparticle contact. Therefore, both bulk and surface carbon play a dominant role in suppressing the growth of titania.

\section{PL studies of $\mathrm{TiO}_{2}$ and $\mathrm{C}-\mathrm{TiO}_{2}$ samples}

The fundamental information regarding energy levels lying within the band gap states can be obtained from PL technique. The PL emission spectrum is used to study the efficiency of charge carrier trapping, their migration and also the fate of photogenerated electron-hole pairs in the semiconductors [31-34]. The PL emission is obtained as a result of recombination of excited electron-hole pair and hence lower $\mathrm{PL}$ intensity indicates efficient charge carrier separation [35,36]. The intense peak observed at $382 \mathrm{~nm}$ is assigned to the band edge luminescence of all the samples (Fig. 7), while peaks in the visible region arise from recombination at dopant levels and oxygen vacancies [3136]. The peak intensity at $382 \mathrm{~nm}$ decreases in the following order: $\mathrm{C}-\mathrm{TiO}_{2}(0.1 \mathrm{wt} \%)>\mathrm{C}-\mathrm{TiO}_{2}(0.08 \mathrm{wt} \%)^{\sim} \mathrm{TiO}_{2}>\mathrm{C}-\mathrm{TiO}_{2}(0.06 \mathrm{wt} \%)$ $>\mathrm{C}-\mathrm{TiO}_{2}(0.04 \mathrm{wt} \%)$. These results show that there is an optimum dopant concentration within the titania lattice to facilitate effective interfacial charge transfer process. At higher dopant concentration, dopant level may act as recombination centers. The PL emission peak at $507 \mathrm{~nm}$ could be assigned to charge transfer from $\mathrm{Ti}^{3+}$ state to the oxygen vacancy in a $\mathrm{TiO}_{6}{ }^{8-}$ octahedra which is observed only in the case of undoped $\mathrm{TiO}_{2}$ [34]. The absence of this peak in doped samples indicates that the oxygen vacancy formation was suppressed by interstitial carbon doping. The peak at $460 \mathrm{~nm}$ arises due to the charge carrier recombination taking place at dopant levels. It was observed that $\mathrm{C}-\mathrm{TiO}_{2}(0.04 \mathrm{wt} \%)$ had the lowest intensity. These results suggests optimal level of trap sites induced by the dopants prevents the recombination of charge carriers at the bulk, while diminishing of surface oxygen vacancies upon doping favors the efficient interfacial charge transfer process.

\section{Effect of dopant concentration}

The photocatalytic activity of the prepared catalysts was evaluated for the degradation of 4-CP under both UV and solar light. The photocatalytic reactivity was estimated by plotting the ratio of residual concentration $(C)$ to the initial concentration $\left(C_{0}\right)$ of $4-\mathrm{CP}$ as a function of irradiation time. The degradation was negligible in the absence of catalyst when the solution was irradiated with UV or solar light for the time period of $3 \mathrm{~h}$. The reactivity of the catalysts under solar light shows the following order: $\mathrm{C}-\mathrm{TiO}_{2}(0.04 \mathrm{wt} \%)>\mathrm{C}-\mathrm{TiO}_{2}$ $(0.06 \mathrm{wt} \%)>\mathrm{C}-\mathrm{TiO}_{2}(0.08 \mathrm{wt} \%)>\mathrm{C}-\mathrm{TiO}_{2}(0.1 \mathrm{wt} \%)>\mathrm{TiO}_{2}$ (Fig. 8), which is in agreement with PL studies. The dopant inside the matrix can suppress or enhance the recombination depending on its concentration and its energy level position. The charge carrier trapping at low dopant concentration may not be obvious and at high concentration they may serve as recombination centers. Thus, optimal dopant concentration is necessary to prolong the lifetime of charge carriers. 
Table 3

The textural parameters of $\mathrm{TiO}_{2}$ and $\mathrm{C}-\mathrm{TiO}_{2}$ photocatalysts.

\begin{tabular}{|c|c|c|c|c|c|}
\hline Photocatalyst & BET surface area $\left(\mathrm{m}^{2} / \mathrm{g}\right)$ & Pore volume $\left(\mathrm{cm}^{3} / \mathrm{g}\right)$ & Pore diameter (nm) & $\begin{array}{l}\text { Particle size in nm } \\
\text { obtained from BET } \\
\text { surface area }\end{array}$ & $\begin{array}{l}\text { Degree of agglomeration } \\
\text { (DA) }\end{array}$ \\
\hline $\mathrm{TiO}_{2}$ & 26.98 & 1.03 & 15.27 & 57.19 & 3.02 \\
\hline $\mathrm{C}-\mathrm{TiO}_{2}(0.04 \mathrm{wt} \%)$ & 55.49 & 2.17 & 15.70 & 28.30 & 1.6 \\
\hline $\mathrm{C}-\mathrm{TiO}_{2}(0.06 \mathrm{wt} \%)$ & 64.48 & 2.30 & 14.30 & 23.96 & 1.4 \\
\hline $\mathrm{C}-\mathrm{TiO}_{2}(0.08 \mathrm{wt} \%)$ & 75.81 & 2.00 & 12.30 & 20.34 & 1.4 \\
\hline $\mathrm{C}-\mathrm{TiO}_{2}(0.1 \mathrm{wt} \%)$ & 94.88 & 2.39 & 14.50 & 16.25 & 1.3 \\
\hline
\end{tabular}

Table 4

Kinetic studies under UV/solar light with UV untreated and UV pretreated $\mathrm{C}-\mathrm{TiO}_{2}$ samples.

\begin{tabular}{|c|c|c|c|c|c|c|}
\hline \multirow[t]{2}{*}{ Photocatalyst } & \multicolumn{2}{|c|}{ UV light } & \multicolumn{2}{|c|}{$\begin{array}{l}\text { Solar light } \\
\text { UV untreated C-TiO }\end{array}$} & \multicolumn{2}{|c|}{$\begin{array}{l}\text { Solar light } \\
\quad \text { UV pretreated } \mathrm{C}-\mathrm{TiO}_{2}\end{array}$} \\
\hline & $\begin{array}{l}\text { Rate constant in } k \times \\
10^{-2} \mathrm{~min}^{-1}\end{array}$ & $\begin{array}{l}\text { Percentage } \\
\text { degradation }\end{array}$ & $\begin{array}{l}\text { Rate constant in } k \times \\
\qquad 10^{-2} \mathrm{~min}^{-1}\end{array}$ & $\begin{array}{l}\text { Percentage } \\
\text { degradation }\end{array}$ & $\begin{array}{l}\text { Rate constant in } k \times \\
\qquad 10^{-2} \mathrm{~min}^{-1}\end{array}$ & Percentage degradation \\
\hline $\mathrm{TiO}_{2}$ & 0.3258 & 46 & 0.0225 & 4 & - & - \\
\hline $\mathrm{C}-\mathrm{TiO}_{2}(0.04 \mathrm{wt} \%)$ & 0.2931 & 42 & 1.5361 & 97 & 0.5128 & 69 \\
\hline $\mathrm{C}-\mathrm{TiO}_{2}(0.06 \mathrm{wt} \%)$ & 0.1977 & 36 & 0.8231 & 81 & 0.4427 & 58 \\
\hline $\mathrm{C}-\mathrm{TiO}_{2}(0.08 \mathrm{wt} \%)$ & 0.1363 & 33 & 0.3258 & 46 & 0.2568 & 39 \\
\hline $\mathrm{C}-\mathrm{TiO}_{2}(0.1 \mathrm{wt} \%)$ & 0.2284 & 22 & 0.1735 & 28 & 0.1103 & 25 \\
\hline
\end{tabular}

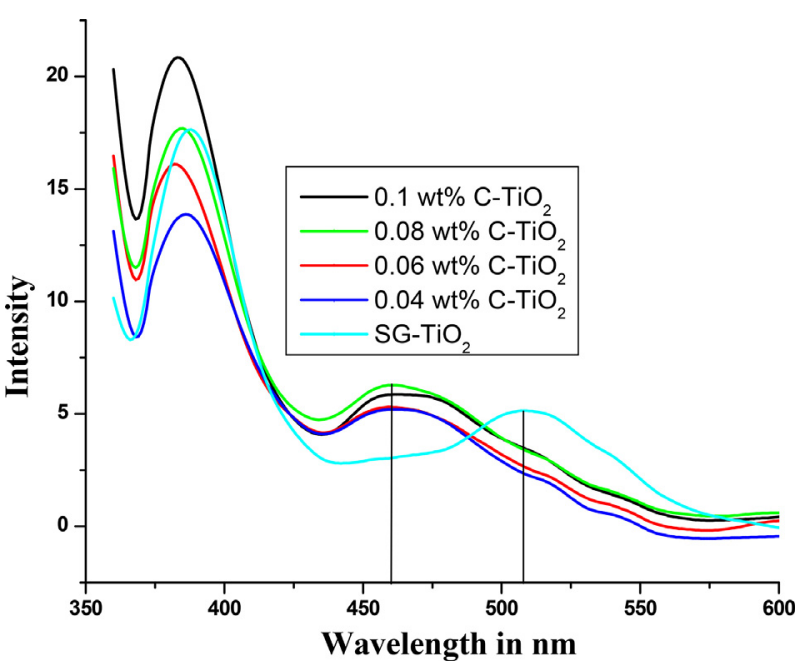

Fig. 7. Photoluminescence spectra of $\mathrm{TiO}_{2}$ and $\mathrm{C}-\mathrm{TiO}_{2}$ photocatalysts.

Beyond the optimum dopant concentration, the rate of recombination starts dominating the reaction in accordance with the following equation:

$K_{\mathrm{RR}} \alpha \exp \left(\frac{-2 R}{a_{0}}\right)$

where $K_{\mathrm{RR}}$ is the rate of recombination, $R$ is the distance separating the electron and hole pairs, and $a_{0}$ is the hydrogenic radius of the wave function for the charge carrier [37-40]. As a consequence, the recombination rate increases exponentially with the dopant concentration. This is because the average distance between the trap sites decreases with increasing number of dopant atoms. On the other hand, the thickness of space charge layer is influenced by the dopant concentration according to the following equation:

$W=\left(\frac{2 \varepsilon \varepsilon_{0} V_{\mathrm{s}}}{e N_{\mathrm{d}}}\right)^{1 / 2}$

where ' $W$ ' is the thickness of space charge layer, $\varepsilon$ and $\varepsilon_{0}$ are the static dielectric constants of the semiconductor and vacuum respectively, $V_{\mathrm{S}}$ is the surface potential, $N_{\mathrm{d}}$ is the number of dopant donor atoms, and $e$ is the electronic charge. The above equation clearly shows that

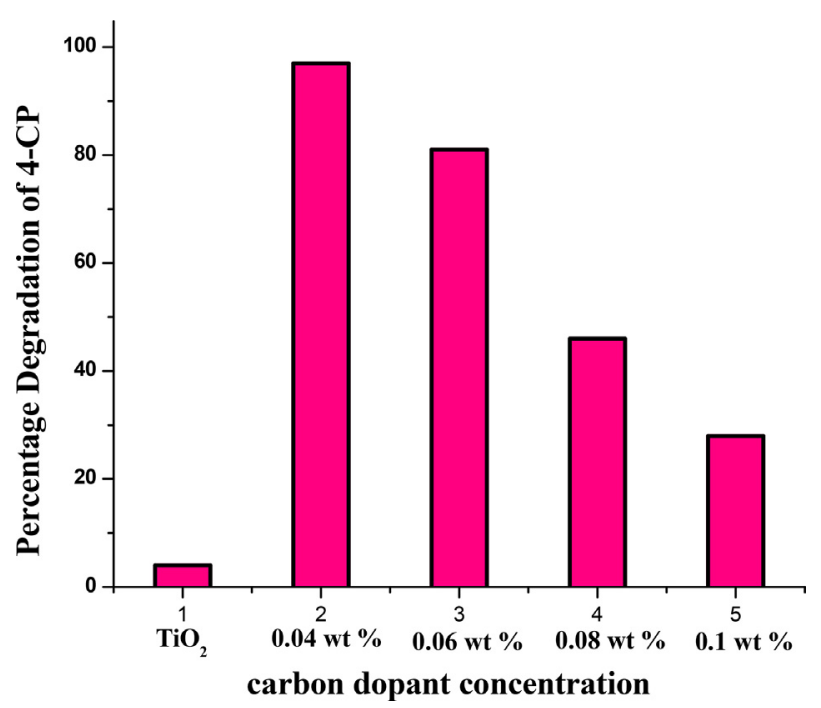

Fig. 8. Percentage degradation of 4-CP under solar light illumination using $\mathrm{TiO}_{2}$ and $\mathrm{C}-\mathrm{TiO}_{2}$ (with various carbon dopant concentration) photocatalysts.

$W$ decreases as the dopant concentration increases. In addition, penetration depth $(l)$ of the light into the solid is given by $l=1 / a$, where ' $a$ ' is the light absorption coefficient at a given wavelength. When the value of $W$ approximates that of $l$, all the photons absorbed by the solid catalyst generate electron-hole pairs that are efficiently separated. Consequently, the existence of optimum value of $N_{\mathrm{d}}$ for which a space charge region exists whose potential is not less than $0.2 \mathrm{eV}$ and whose thickness is more or less equal to light penetration depth can be understood by above equations $[41,42]$. In the present case, optimum value of $N_{\mathrm{d}}$ approximates to that of $0.04 \mathrm{wt} \%$. For higher dopant concentration $(>0.04 \mathrm{wt} . \%)$, the space charge region may become narrow and the penetration depth of light into $\mathrm{TiO}_{2}$ greatly exceeds the thickness of the space charge layer. The charge carriers thus generated beyond the space charge region are not under the influence of electric/potential field and hence recombine rapidly. At high dopant concentrations, the dopant level itself can act as recombination sites for the charge carriers evidently decreasing the photocatalytic activity. 
Table 5

Intermediates formed during the degradation reaction at two different time intervals by GC-MS technique.

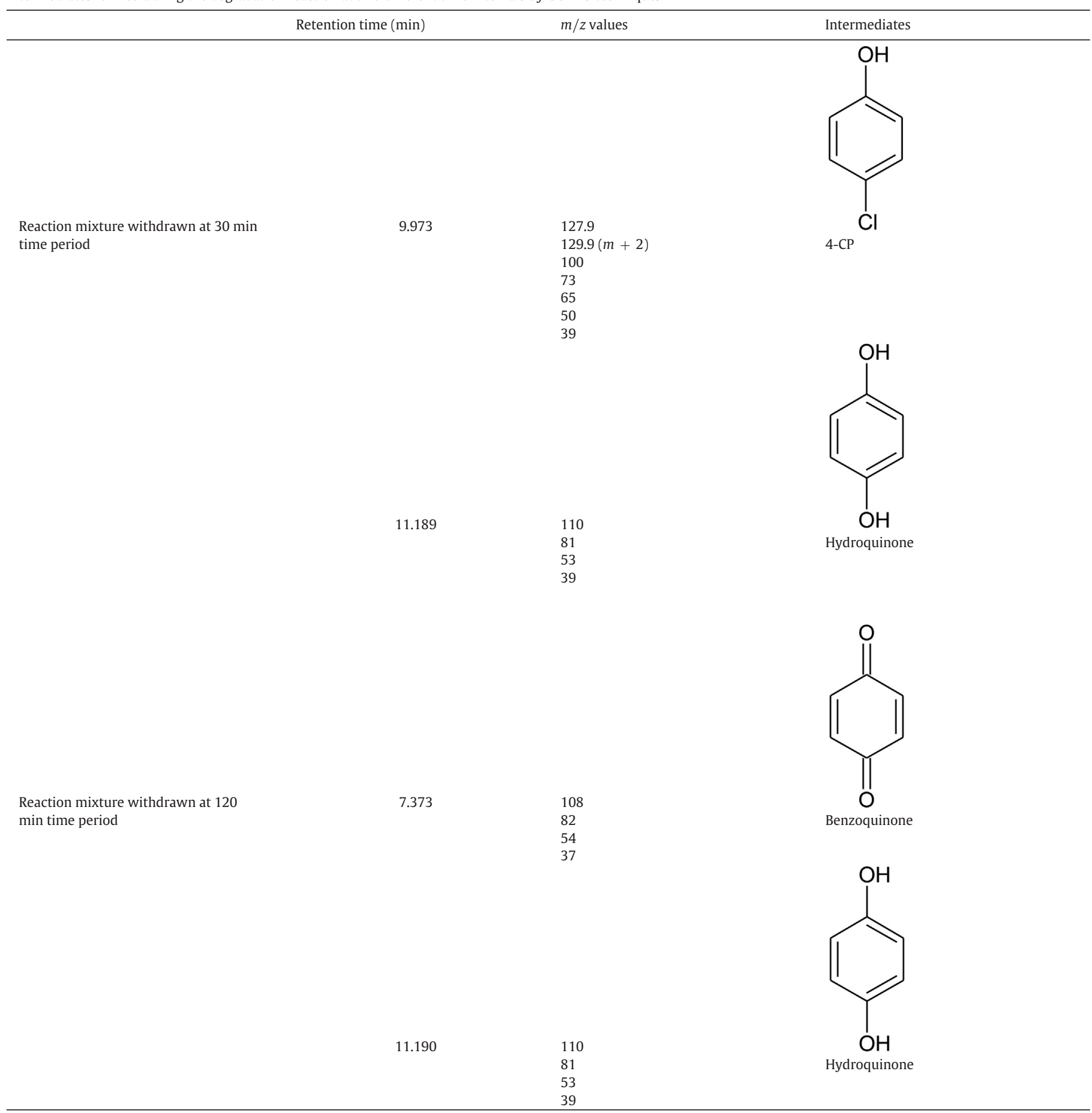

\section{Photocatalytic activity of $\mathrm{TiO}_{2}$ and $\mathrm{C}-\mathrm{TiO}_{2}$ photocatalysts}

Fig. 9(a) and (b) shows the relative concentration changes of 4CP with irradiation time for $\mathrm{TiO}_{2}$ and $\mathrm{C}-\mathrm{TiO}_{2}$ under UV and solar light irradiation. To quantitatively understand the reaction kinetics of pollutant degradation, we analyzed the degradation data with the pseudo-first-order kinetic model, which is generally suited for the photocatalytic degradation, since the initial concentration of the pollutant is low:

$\ln \left(\frac{C}{C_{o}}\right)=-k t$ where $C_{0}$ and $C$ are the concentration of the 4-CP in solution at time 0 and $t$ respectively and $k$ is the pseudo-first-order rate constant [43]. By plotting $\ln \left(C / C_{0}\right)$ as a function of irradiation time (Figs. S2 and S3), the constant $k$ is calculated from the slopes of the fitted straight lines. The experimental data obtained fit well with the pseudo first order reaction kinetics. The plots show two different linear stages indicating that the photocatalytic degradation follows pseudo first order kinetics in two stages. The rate constant for the second stage is higher than the first stage. In the first stage it is proposed that hydroxyl free radicals attack the 4-CP molecule showing a moderate rate. In the second stage the hydroxyl radicals might attack the intermediate products 
formed during the degradation process at a faster rate and hence shows a higher rate constant. This deviation is higher for $\mathrm{TiO}_{2}$ and $\mathrm{C}-\mathrm{TiO}_{2}(0.04 \mathrm{wt} \%)$ catalysts under UV and solar light respectively. The observed rate constants for these catalysts in both the linear stages are high under the respective illuminations. Under UV light all the $\mathrm{C}-\mathrm{TiO}_{2}$ samples showed poor activity compared to $\mathrm{TiO}_{2}$. The reactivity of various catalysts in the presence of UV light shows the following order: $\mathrm{TiO}_{2}>\mathrm{C}-\mathrm{TiO}_{2}(0.04 \mathrm{wt} \%)>\mathrm{C}-\mathrm{TiO}_{2}(0.06 \mathrm{wt} \%)>\mathrm{C}-\mathrm{TiO}_{2}(0.08 \mathrm{wt} \%)>$ $\mathrm{C}-\mathrm{TiO}_{2}(0.1 \mathrm{wt} \%)$. This poor activity of $\mathrm{C}-\mathrm{TiO}_{2}$ samples was attributed to the dopant inside the titania matrix serving as recombination centers under UV light. This is because electron/hole trapped at dopant sites recombines with mobile counter parts, i.e., trapped hole reacts with free electron or trapped electron reacts with free holes [1]. The origin of photocatalytic activity of $\mathrm{C}-\mathrm{TiO}_{2}$ samples under solar light irradiation is ascribed to the presence of interstitial carbon doping in $\mathrm{TiO}_{2}$. The calculated values of $\mathrm{VB}$ edge positions of $\mathrm{C}-\mathrm{TiO}_{2}$ indicate that the impurity dopant levels move further away from VB when the carbon atom is interstitially doped inside $\mathrm{TiO}_{2}$ lattice via $\mathrm{O}-\mathrm{Ti}-\mathrm{C}$ and $\mathrm{Ti}-\mathrm{O}-\mathrm{C}$ bonds (Table 2). This interior extension of VB within $\mathrm{TiO}_{2}$ band gap is due to interstitial carbon doping which enables C$\mathrm{TiO}_{2}$ to show good absorption in the visible region. The XPS studies confirm that the carbon is present in the interstitial position in the $\mathrm{TiO}_{2}$ lattice narrowing of the band gap of $\mathrm{C}-\mathrm{TiO}_{2}$ via $\mathrm{O}-\mathrm{Ti}-\mathrm{C}$ and $\mathrm{Ti}-\mathrm{O}-\mathrm{C}$ bonds. The presence of interstitial carbon improves the degree of separation and also restrains the recombination of photogenerated charge carriers in $\mathrm{C}-\mathrm{TiO}_{2}$, which is conducive in improving the photocatalytic ability of the catalysts $[44,45]$. The interstitial carbon dopant level above the VB renders efficient visible light absorption while, the poor activity of undoped $\mathrm{TiO}_{2}$ under solar light is due to inefficient absorption of visible light energy. The PL intensity of $\mathrm{TiO}_{2}$ is much higher than $\mathrm{C}-\mathrm{TiO}_{2}(0.04 \mathrm{wt} \%)$ indicating that carbon doping can effectively inhibit the recombination of excited electron and hole which is attributed to the trapping of holes by the water molecules or surface hydroxyl groups to form hydroxyl free radicals and the electrons by surface adsorbed oxygen molecules to form superoxide radicals. The XPS and FTIR results indicate the presence of carbonaceous species on $\mathrm{TiO}_{2}$ surface which may serve as photosensitizer and facilitate $\mathrm{C}-\mathrm{TiO}_{2}$ to absorb more visible light through the surface modification [46]. Under mechanical grinding conditions used here, it is believed that surface carbonaceous species is present on the $\mathrm{TiO}_{2}$ surface via $\mathrm{Ti}-\mathrm{O}-\mathrm{C}$ bonds which is desirable for favorable charge carrier transfer upon light excitation [47]. The carbonaceous species embedded on the $\mathrm{TiO}_{2}$ matrix leads to the formation of new active sites, which are also responsible for the observed higher photocatalytic activity. Upon visible light irradiation, multiple charge transfer process can take place; (i) electron transition takes place from dopant carbon level to CB of titania; (ii) surface carbonaceous species gets excited and transfers the electron to $\mathrm{CB}$ of titania. This is based on the rationale that, excited energy level of surface carbon is at higher position than the $\mathrm{CB}$ of titania, which thermodynamically favors the charge transfer pathways. The carbonaceous species on the surface acts as a photosensitizer for $\mathrm{TiO}_{2}$. Alternatively Lettmann et al. have proposed that after excitation of the photosensitizer, singlet oxygen is formed by a triplet-triplet energy transfer [46]. An electron can be transferred directly from the excited photosensitizer to triplet oxygen to generate the superoxide radical anion. The singlet oxygen and superoxide radical anion are capable of degrading organic compounds. The electron transfer rate to oxygen molecules adsorbed on the $\mathrm{TiO}_{2}$ surface increases the dioxygen reduction with subsequent formation of free radicals which accelerates the rate of 4-CP degradation [4851].

To further evaluate the potential reactivity of surface carbonaceous species as sensitizer, all the $\mathrm{C}-\mathrm{TiO}_{2}$ samples were preirradiated under UV light ( $>330 \mathrm{~nm}$ ) for $1 \mathrm{~h}$ to eliminate it. The sample after preirradiation reduced its color from dark brown to light brown implicating the removal of surface carbonaceous species as confirmed by

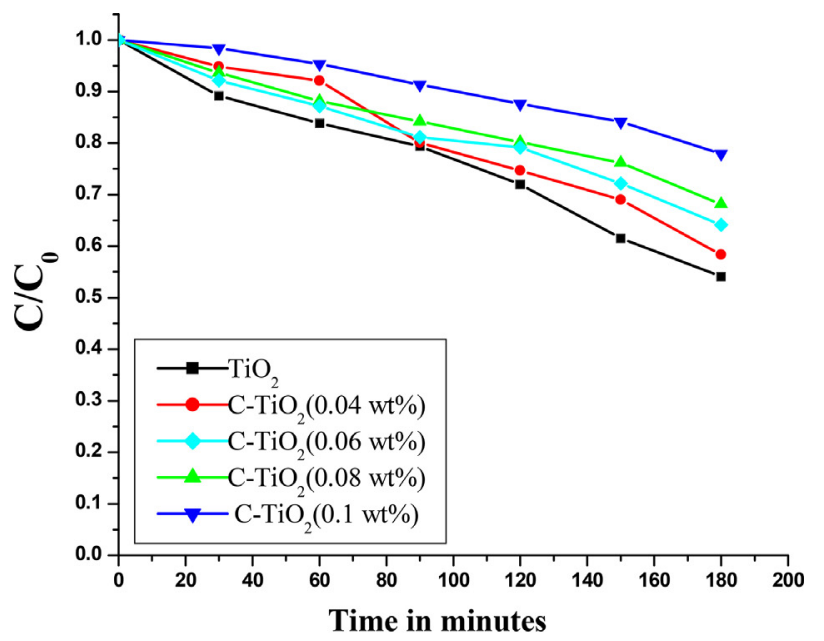

(a)

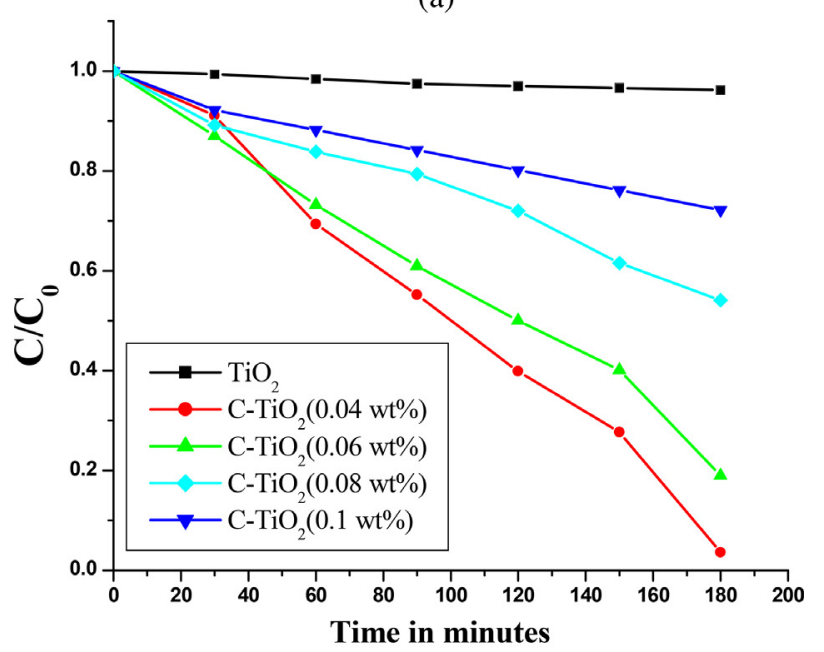

(b)

Fig. 9. (a) Plot of $C / C_{0}$ versus time in minutes for the degradation of 4-CP under UV light illumination using $\mathrm{TiO}_{2}$ and $\mathrm{C}-\mathrm{TiO}_{2}$ samples. (b) Plot of $C / C_{0}$ versus time in minutes for the degradation of 4-CP under visible light illumination using $\mathrm{TiO}_{2}$ and $\mathrm{C}-\mathrm{TiO}_{2}$ samples.

the absence of peaks at 286 and $287.4 \mathrm{eV}$ in the XPS (data not shown). Table 4 shows the rate constant values for photocatalytic degradation of 4-CP under visible light irradiation. Further it can be observed that all UV pretreated samples showed comparatively lower activity than UV untreated C-TiO 2 samples (Fig. 10). The lower activity of UV pretreated samples is attributed to the removal of surface carbon on the $\mathrm{TiO}_{2}$ lattice which eliminated the photosensitization process. UV light pretreatment removes the surface carbonaceous species by the oxidation reaction of carbon to carbon dioxide [10]. But these samples still showed better activity under visible light irradiation compared to $\mathrm{TiO}_{2}$ samples due to the excitation of electrons from the impurity levels induced by carbon doping indicating that UV pretreatment removed only the surface carbonaceous species and not the interstitial carbon inside the $\mathrm{TiO}_{2}$ lattice. From these results, we observe that the enhanced activity of the UV untreated $\mathrm{C}-\mathrm{TiO}_{2}$ samples is due to the synergistic effects of both interstitial carbon and surface carbonaceous species. The surface area of the $\mathrm{C}-\mathrm{TiO}_{2}(0.04 \mathrm{wt} \%)$ was higher than the $\mathrm{TiO}_{2}$ which enables efficient adsorption of pollutants on the surface due to the increase in the number of surface active sites. However from the results, it can be inferred that high surface area and smaller crystallite size alone do not contribute for the activity but optimum dopant concentration plays a major role.

The surface area for most of the doped samples was higher than 


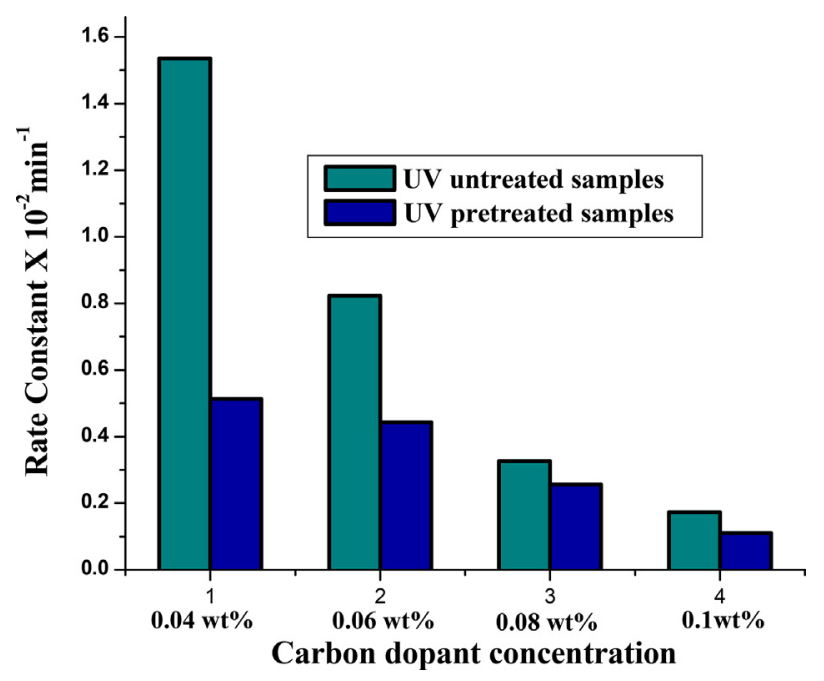

Fig. 10. Rate constant versus carbon dopant concentration for both UV untreated and UV pretreated samples for the degradation of 4-CP under solar light illumination.

$\mathrm{TiO}_{2}$ sample. Larger surface area may be one of the important factors for the photocatalytic degradation reactions, as large amount of pollutant can be adsorbed promoting the interfacial charge transfer rate. However the photocatalysts with larger surface area is usually associated with large amount of crystalline defects favoring the recombination of electron-hole pairs leading to low photocatalytic activity at higher dopant concentrations. Hence larger surface area is a requirement but cannot be a decisive factor [40].

\section{Study of reaction intermediates by GC-MS technique}

The formation of intermediates during the degradation process was identified by GC-MS technique. The sample was withdrawn from the reaction mixture at the time interval of $30 \mathrm{~min}$ and it was extracted in the organic solvent. This sample showed a chromatogram with retention time of 9.973 and 11.189 min. The corresponding mass spectra recorded at the retention time 9.973 min showed molecular ion peak corresponding to $m / z$ of $4-C P$ at 127.9 and $(m+2)$ peak at 129.9 in the ratio of $3: 1$. The $m / z$ peak at 11.189 in the spectra can be attributed to the formation of hydroquinone as a result of hydroxyl radical attack resulting in the elimination of $-\mathrm{Cl}$ group, followed by subsequent oxidation. The sample after $120 \mathrm{~min}$ of irradiation showed two peaks at retention time 7.373 and $11.190 \mathrm{~min}$ in GC spectra corresponding to benzoquinone and hydroquinone respectively. The sample after $180 \mathrm{~min}$ has not shown any major peaks implying the complete degradation of $4-\mathrm{CP}$. The GC-MS results are given in Table 5 .

\section{Conclusion}

The carbon was doped into titania matrix using commercially available anhydrous D-glucose as the carbon source. Carbon occupied interstitial positions in $\mathrm{TiO}_{2}$ lattice and it was also distributed as carbonaceous species on the surface. The high activity of $\mathrm{C}-\mathrm{TiO}_{2}$ for photocatalytic degradation of 4-CP under visible light was attributed to synergistic effect of doped interstitial carbon and surface carbonaceous species. The doped carbon induces trap sites within the band gap which inhibits the recombination in the bulk at optimum dopant level. The surface carbon suppresses the formation of oxygen vacancies, additionally contributing to overall activity by photosensitization process. Hydroquinone and benzoquinone are the major reaction intermediates as confirmed by the GC-MS technique.

\section{Acknowledgements}

The authors acknowledge University Grants Commission (UGC) and Department of Science and Technology (DST-IDP \& DST-SERC), Government of India for their financial supports.

\section{Appendix A. Supplementary data}

Supplementary data associated with this article can be found, in the online version, at http://dx.doi.org/10.1016/j.jece.2014.02.016.

\section{References}

[1] M.R. Hoffman, S.T. Martin, W. Choi, D.W. Bahnemann, Environmental applications of semiconductor photocatalysis, Chemical Reviews. 95 (1995) 69-96. http://dx.doi.org/10.1021/cr00033a004.

[2] S.G. Kumar, L.G. Devi, Review on modified $\mathrm{TiO}_{2}$ photocatalysis under UV/visible light: selected results and related mechanisms on interfacial charge Carrier transfer, Dynamics, Journal of Physical Chemistry. Part A. 115 (2011) 13211-41. http://dx.doi.org/10.1021/jp204364a.

[3] L.G. Devi, S.G. Kumar, Strategies developed on the modification of titania for visible light response with enhanced interfacial charge transfer process: an overview, Central European Journal of Chemistry. 9 (2011) 959-61. http://dx. doi.org/10.2478/s11532-011-0084-9.

[4] J. Zhang, Y. Wu, M. Xing, S.A.K. Leghari, S. Sajjad, Development of modified N doped $\mathrm{TiO}_{2}$ photocatalyst with metals, nonmetals and metal oxides, Energy \& Environmental Science. 3 (2010) 715-26. http://dx.doi.org/10.1039/b927575d.

[5] L.G. Devi, R. Kavitha, A review on non metal ion doped titania for the photocatalytic degradation of organic pollutants under UV/solar light: role of charge carrier dynamics in enhancing the activity, Applied Catalysis. Part B : Environmental. 140-141 (2013) 559-87. http://dx.doi.org/10.1016/j.apcatb.2013.04.035.

[6] M.V. Dozzi, E. Selli, Doping $\mathrm{TiO}_{2}$ with p-block elements: effects on photocatalytic activity, Journal of Photochemistry and Photobiology, Part C : Photochemistry Reviews. 14 (2013) 13-28. http://dx.doi.org/10.1016/j.jphotochemrev.2012.09. 002 .

[7] D. Mitoraj, H. Kisch, The nature of nitrogen-modified titanium dioxide photocatalysts active in visible light, Angewandte Chemie (International Ed. in English). 47 (2008) 9975-8. http://dx.doi.org/10.1002/anie.200800304, 19006158.

[8] C.D. Valentin, G. Pacchioni, A. Selloni, Theory of carbon doping of titanium dioxide, Chemistry of Materials. 17 (2005) 6656-65. http://dx.doi.org/10.1021/ cm051921h.

[9] M. Janus, M. Inagaki, B. Tryba, M. Toyoda, A.W. Moraswski, Carbon modified $\mathrm{TiO}_{2}$ photocatalyst by ethanol carbonization, Applied Catalysis. Part B : Environmental. 63 (2006) 272-6. http://dx.doi.org/10.1016/j.apcatb.2005.10.005.

[10] L.G. Devi, G.M. Krishnaiah, Photocatalytic degradation of p-amino-azobenzene using various heat treated $\mathrm{TiO}_{2}$ as the photocatalyst, Journal of Photochemistry and Photobiology, Part A : Chemistry. 121 (1999) 141-5. http://dx.doi.org/10. 1016/S1010-6030(98)00389-X.

[11] Y. Park, W. Kim, H. Park, T. Tachikawa, T. Majima, W. Choi, Carbon-doped $\mathrm{TiO}_{2}$ photocatalyst synthesized without using an external carbon precursor and the visible light activity, Applied Catalysis. Part B : Environmental. 91 (2009) 35561. http://dx.doi.org/10.1016/j.apcatb.2009.06.001.

[12] (a) C.G. Hatchard, C.A. Parker, A new sensitive chemical actinometer. I. Some trials with potassium ferrioxalate, Proceedings of the Royal Society Series A. 220 (1953) 104-15. http://dx.doi.org/10.1098/rspa.1953.0175; $\quad$ (b) C.G. Hatchard, C.A. Parker, A new sensitive chemical actinometer. II. Potassiumferrioxalate as a standard as a standard chemical actinometer, Proceedings of the Royal Society Series A. 235 (1956) 518-36. http://dx.doi.org/10.1098/rspa.1956.0102.

[13] G. An, W. Ma, Z. Sun, Z. Liu, B. Han, S. Miao, et al, Preparation of titania/ carbon nanotube composites using supercritical ethanol and their photocatalytic activity for phenol degradation under visible light irradiation, Carbon. 45 (2007) 1795-801. http://dx.doi.org/10.1016/j.carbon.2007.04.034.

[14] T. Xu, W. Hou, X. Shen, H. Wu, X. Li, J. Wang, et al, Sulfonated titania submicrospheres-doped sulfinated poly(ether ether ketone) hybrid membranes with enhanced proton conductivity and reduced methanol permeability, Journal of Power Sources. 196 (2011) 4934-42. http://dx.doi.org/10.1016/j.jpowsour. 2011.02.017.

[15] J.G.Yu, G.H.Wang, B. Cheng, M.H.Zhou, Effects of hydrothermal temperature and time on the photocatalytic activity and microstructures of bimodal mesoporous $\mathrm{TiO}_{2}$ powders, Applied Catalysis. Part B : Environmental. 69 (2007) 171-80. http://dx.doi.org/10.1016/j.apcatb.2006.06.022.

[16] N.I. Kovtyukhova, T.E. Mallouk, L. Pan, E.C. Dickey, Individual single-walled nanotubes and hydrogels made by oxidative exfoliation of carbon nanotube ropes, Journal of the American Chemical Society. 125 (2003) 9761-9. http: //dx.doi.org/10.1021/ja0344516, 12904042.

[17] S. Sakthivel, H. Kisch, Daylight photocatalysis by carbon-modified titanium dioxide, Angewandte Chemie (International Ed. in English). 42 (2003) 4908-11. http://dx.doi.org/10.1002/anie.200351577, 14579435.

[18] Y. Li, D.S. Hwang, N.H. Lee, S.J. Kim, Synthesis and characterization of carbondoped titania as an artificial solar light sensitive photocatalyst, Chemical Physics Letters. 404 (2005) 25-9. http://dx.doi.org/10.1016/j.cplett.2005.01.062. 
[19] L. Wan, J.F. Li, J.Y. Feng, W. Sun, Z.Q. Mao, Anatase $\mathrm{TiO}_{2}$ films with $2.2 \mathrm{eV}$ band gap prepared by micro-arc oxidation, Materials Science and Engineering B. 139 (2007) 216-20. http://dx.doi.org/10.1016/j.mseb.2007.02.014.

[20] J. Zhang, J. Xi, Z. Ji, Mo $+\mathrm{N}$ codoped $\mathrm{TiO}_{2}$ sheets with dominant $\{001\}$ facets for enhancing visible-light photocatalytic activity, Journal of Materials Chemistry. 22 (2012) 17700-8. http://dx.doi.org/10.1039/c2jm32391e.

[21] H. Wang, Z. Wu, Y. Liu, A simple two-step template approach for preparing carbon-doped mesoporous $\mathrm{TiO}_{2}$ hollow microspheres, Journal of Physical Chemistry C. 113 (2009) 13317-32. http://dx.doi.org/10.1021/jp9047693.

[22] A.L. Linsebigler, G. Lu, J.T. Yates, Photocatalysis on surfaces: principles, mechanisms, and selected results, Chemical Reviews. 95 (1995) 735-58. http://dx.doi. org/10.1021/cr00035a013.

[23] J. Lu, H. Jin, Y. Dai, K. Yang, B. Huang, Effect of electronegativity and charge balance on the visible-light-responsive photocatalytic activity of Non metal doped anatase $\mathrm{TiO}_{2}$, International Journal of Photoenergy. (2012) 928503.

[24] J. Yu, J. Ran, Facile preparation and enhanced photocatalytic $\mathrm{H}_{2}$-production activity of $\mathrm{Cu}(\mathrm{OH})_{2}$ cluster modified $\mathrm{TiO}_{2}$, Energy \& Environmental Science. 4 (2011) 1364-71. http://dx.doi.org/10.1039/c0ee00729c.

[25] K. Hashimato, H. Irie, A. Fujishima, $\mathrm{TiO}_{2}$ photocatalysis: a historical overview and future prospects, Japanese Journal of Applied Physics. 44 (2005) 8269-85. http://dx.doi.org/10.1143/JJAP.44.8269.

[26] V. Etacheri, G. Michlits, M.K. Seery, S.J. Hinder, S.C. Pillai, A highly efficient $\mathrm{TiO}_{2}$ $\mathrm{xCx}$ nano-heterojunction photocatalyst for visible light induced antibacterial applications, ACS Applied Materials \& interfaces. 5 (2013) 1663-72. http://dx. doi.org/10.1021/am302676a, 23379473.

[27] K.B. Jaimy, S. Ghosh, S. Sankar, K.G.K. Warrier, An aqueous sol-gel synthesis of chromium (111) doped mesoporous titanium dioxide for visible light photocatalysis, Materials Research Bulletin. 46 (2011) 914-21. http://dx.doi.org/10. 1016/j.materresbull.2011.02.030.

[28] M. Pelaez, A.L. Cruz, E. Stathatos, P. Falaras, D.D. Dionysiou, Visible lightactivated $\mathrm{N}-\mathrm{F}$-codoped $\mathrm{TiO}_{2}$ nanoparticles for the photocatalytic degradation of microcystin-LR in waters, Catalysis Today. 144 (2009) 19-25. http://dx.doi. org/10.1016/j.cattod.2008.12.022.

[29] D. Friedmann, C. Mendive, D. Bahnemann, $\mathrm{TiO}_{2}$ for water treatment: parameters affecting the kinetics and mechanisms of photocatalysis, Applied Catalysis. Part B : Environmental. 99 (2010) 398-406. http://dx.doi.org/10.1016/j.apcatb.2010. 05.014 .

[30] J. Lin, J.C. Yu, An investigation on photocatalytic activities of mixed $\mathrm{TiO}_{2}$-rare earth oxides for the oxidation of acetone in air, Journal of Photochemistry and Photobiology A: Chemistry. 116 (1998) 63-7. http://dx.doi.org/10.1016 S1010-6030(98)00289-5.

[31] J.L. Zhang, Y. Hu, M. Matsuoka, H. Yamashita, M. Minagawa, H. Hidaka, et al, Relationship between the local structures of titanium oxide Photocatalysts and their reactivities in the decomposition of NO, Journal of Physical Chemistry. Part B. 105 (2001) 8395-8. http://dx.doi.org/10.1021/jp012080e.

[32] J.C. Yu, J.G. Yu, W.K. Ho, Z.T. Jiang, Z.L. Zhang, Effects of $\mathrm{F}^{-}$doping on the photocatalytic activity and microstructures of nanocrystalline $\mathrm{TiO}_{2}$ powders, Chemistry of Materials. 14 (2002) 3808-16. http://dx.doi.org/10.1021/cm020027c.

[33] J.G. Yu, H.G. Yu, B. Cheng, X.J. Zhao, J.C. Yu, W.K. Ho, The effect of calcination temperature on the surface microstructure and photocatalytic activity of $\mathrm{TiO}_{2}$ thin films prepared by liquid phase deposition, Journal of Physical Chemistry. Part B. 107 (2003) 13871-9. http://dx.doi.org/10.1021/jp036158y.

[34] B. Neumann, P. Bogdanoff, H. Tributsch, S. Sakthivel, H. Kisch, Electrochemica mass spectroscopic and surface photovoltage studies of catalytic water photooxidation by undoped and carbon-doped titania, Journal of Physical Chemistry. Part B. 109 (2005) 16579-86. http://dx.doi.org/10.1021/jp051339g, 16853109.

[35] H. Tang H. Berger, P.E. Schmid, F. Levy, G. Burri, Photoluminescence in TiO anatase single crystals, Solid State Communications. 87 (1993) 847-50. http: //dx.doi.org/10.1016/0038-1098(93)90427-0.

[36] H. Tang, K. Prasad, R. Sanjinbs, P.E. Schmid, F. Levy, Electrical and optical properties of $\mathrm{TiO}_{2}$ anatase thin films, Journal of Applied Physics. 75 (1994) 2024-47.
[37] A.W. Xu, Y. Gao, H.Q. Liu, The preparation, characterization, and their photocatalytic activities of rare-earth-doped $\mathrm{TiO}_{2}$ nanoparticles, Journal of Catalysis. 207 (2002) 151-7. http://dx.doi.org/10.1006/jcat.2002.3539.

[38] Devi L. Gomathi, Murthy B. Narasimha, Kumar S. Girish, Heterogeneous photo catalytic degradation of anionic and cationic dyes over $\mathrm{TiO}_{2}$ and $\mathrm{TiO}_{2}$ doped with $\mathrm{Mo}^{6+}$ ions under solar light: correlation of dye structure and its adsorptive tendency on the degradation rate, Chemosphere. 76 (2009) 1163-6. http://dx. doi.org/10.1016/j.chemosphere.2009.04.005, 19439341.

[39] L.G. Devi, N. Kottam, S.G. Kumar, K.E. Rajashekhar, Preparation, characterization and enhanced photocatalytic activity of $\mathrm{Ni}^{2+}$ doped titania under solar light, Central European Journal of Chemistry. 8 (2010) 142-8. http://dx.doi.org/10. 2478/s11532-009-0115-y.

[40] L.G. Devi, S.G. Kumar, Influence of physicochemical-electronic properties of transition metal ion doped polycrystalline titania on the photocatalytic degradation of indigo carmine and 4-nitrophenol under UV/solar light, Applied Surface Science. 257 (2011) 2779-90. http://dx.doi.org/10.1016/j.apsusc.2010.10.062.

[41] Y. Pleskov, Conversion of luminous energy into electrical and chemical energy in photoelectrochemical cells with semiconductor electrodes, Soviet Electrochemistry. 17 (1981) 1-25.

[42] L.G. Devi, S.G. Kumar, Exploring the critical dependence of adsorption of various dyes on the degradation rate using $\mathrm{Ln}^{3+}-\mathrm{TiO}_{2}$ surface under $\mathrm{UV} /$ solar light, Applied Surface Science. 261 (2012) 137-46. http://dx.doi.org/10.1016/j.apsusc. 2012.07.121.

[43] X.H. Wang, J.G. Li, H. Kamiyama, Y. Moriyoshi, T. Ishigaki, Wavelength-sensitive photocatalytic degradation of methyl orange in aqueous suspension over iron(III)-doped $\mathrm{TiO}_{2}$ nanopowders under UV and visible light irradiation, journal of Physical Chemistry. Part B. 110 (2006) 6804-9. http://dx.doi.org/10.1021/ jp060082z, 16570988.

[44] H. Li, D. Wang, H. Fan, P. Wang, T. Jiang, T. Xie, Synthesis of highly efficient C-doped $\mathrm{TiO}_{2}$ photocatalyst and its photogenerated charge-transfer properties, Journal of Colloid and Interface Science. 354 (2011) 175-80. http://dx.doi.org/ 10.1016/j.jcis.2010.10.048, 21074165.

[45] T. Wu, G. Liu, J. Zhao, H. Hidaka, N. Serpone, Photoassited degradation of dye pollutants. V. Self-photosensitized oxidative transformation of rhodamine B under visible light Irradiation in aqueous $\mathrm{TiO}_{2}$ dispersions, Journal of Physical Chemistry. Part B. 102 (1998) 5845-51. http://dx.doi.org/10.1021/jp980922c.

[46] C. Lettmann, K. Hildenbrand, H. Kisch, W. Macyk, W.F. Maier, Visible light photodegradation of 4-chlorophenol with a coke-containing titanium dioxide photocatalyst, Applied Catalysis. Part B : Environmental. 32 (2001) 215-27. http://dx.doi.org/10.1016/S0926-3373(01)00141-2.

[47] M. Niederberger, G. Garnweitner, F. Krumeich, R. Nesper, H. Colfen, M. Antonietti, Tailoring the surface and solubility properties of nanocrystalline titania by a non aqueous in situ functionalization process, Chemistry of Materials. 16 (2004) 1202-8. http://dx.doi.org/10.1021/cm031108r.

[48] M. Mrowetz, E. Selli, $\mathrm{H}_{2} \mathrm{O}_{2}$ evolution during the photocatalytic degradation of organic molecules on fluorinated $\mathrm{TiO}_{2}$, New Journal of Chemistry. 30 (2006) 108-14. http://dx.doi.org/10.1039/b511320b.

[49] B. Tian, J. Zhang, T. Tong, F. Chen, Preparation of $\mathrm{Au} / \mathrm{TiO}_{2}$ catalysts from $\mathrm{Au}(\mathrm{I})$ thiosulfate complex and study of their photocatalytic activity for the degradation of methyl orange, Applied Catalysis. Part B : Environmental. 79 (2008) 394-401. http://dx.doi.org/10.1016/j.apcatb.2007.11.001.

[50] J.R. Raji, K. Palanivelu, Sunlight-induced photocatalytic degradation of organic pollutants by carbon-modified nanotitania with vegetable oil as precursor, Industrial and Engineering Chemistry Research. 50 (2011) 3130-8. http://dx.doi.org/10.1021/ie101259p.

[51] L.G. Devi, R. Kavitha, Enhanced photocatalytic activity of sulfur doped $\mathrm{TiO}_{2}$ for the decomposition of phenol: a new insight into the bulk and surface modification, Materials Chemistry and Physics. 143 (2014) 1300-8. http://dx.doi.org/10. 1016/j.matchemphys.2013.11.038. 